\title{
Career transitions and employability ${ }^{\text {it }}$
}

\author{
${\text { Ans De } \operatorname{Vos}^{\mathrm{a}}{ }, \text {, Sofie Jacobs }^{\mathrm{a}} \text {, Marijke Verbruggen }}^{\mathrm{b}}$ \\ a Antwerp Management School, University of Antwerp, Belgium \\ ${ }^{\mathrm{b}} \mathrm{KU}$ Leuven, Belgium
}

\section{A R T I C L E INF O}

\section{Keywords:}

Career transitions

Employability

Organizational psychology

Vocational psychology

\begin{abstract}
A B S T R A C T
How individuals can be employable and make successful career transitions throughout their working life is gaining increased attention from scholars in the field of vocational and organizational psychology for several decades now. Although contemporary career literature implicitly or explicitly assumes a strong connectedness between career transitions and employability, these two concepts have their own historical development in the literature. In this paper we provide a historical account of how the research fields around both have evolved, and we highlight some key insights from seminal work. We then review the literature to explore in more detail how the relationship between career transitions and employability has been empirically studied in the vocational and organizational psychology literature so far. We end with discussing the major observations from this review and formulate pathways for future research.
\end{abstract}

\section{Introduction}

In the so-called 'new career era', career transitions and employability have gained increased attention from scholars in the field of vocational and organizational psychology (Forrier et al., 2009; Fouad and Kozlowski, 2019; Savickas, 2011). Both concepts are not new though, and they have been widely studied from diverse angles since several decades. Although contemporary career literature implicitly or explicitly assumes a strong connectedness between both, these two concepts have their own historical development in the literature. In this paper, we first provide a historical account of how the research fields around both have evolved, and we highlight some key insights regarding the conceptual relatedness of both concepts. Then, we review the literature to explore in more detail how the relationship between career transitions and employability has been empirically studied in the vocational and organizational psychology literature.

A career is defined as the sequence of work experiences that evolve over the individual's life course (Arthur et al., 1989), and refers to the movement of a person through time and social space. First, regarding the element of time, research on career dynamics has long focused on career stages that were interpreted to occur in parallel with adult development or life stages (e.g., Dalton et al., 1977; Hall, 1976; Nicholson and West, 1989; Super, 1957). Yet, in the contemporary career context, it is generally acknowledged that there is no such thing as one idealized career path characterized by a set of predictable transitions all workers go through at specific points in their life (De Vos et al., 2019). The idea of 'one-life-one-career' (Sarason, 1977) is changing towards a focus on adapting one's career identity and continuously acquiring new knowledge and skills throughout the life-span (Direnzo and Green-

\footnotetext{
is Our work is supported by the Flemish Fund for Scientific Research, as part of the EOS research grant EOS Grant CARST G0E8318N (EOS number 30987235).

* Corresponding author at: Antwerp Management School, University of Antwerp, Department of Management, Faculty of Economics and Business, Boogkeers 5, 2000 Antwerp, Belgium.

E-mail addresses: ans.devos@ams.ac.be (A. De Vos); sofie.jacobs@ams.ac.be (S. Jacobs); marijke.verbruggen@kuleuven.be (M. Verbruggen)
} 
haus, 2011; Fouad and Kozlowski, 2019; Savickas, 2011), leading to much more complex and idiosyncratic career patterns, thereby making the individual employee the central actor (De Vos et al., 2019; Forrier et al., 2018).

Second, the work experiences encompassing an individual's career take place through the sequence of positions they occupy within the social space of a career field, an occupation, or an organization (Chudzikowski, 2012; Forrier et al., 2009). Career transitions refer to the moves within or across those social spaces, meaning that every move from one position to another can be considered as a career transition (Chudzikowski, 2012). As such, career transitions encompass much more than the transition from school to work or from unemployment to work; they are a recurring issue throughout the lifespan (Savickas, 2011). Career moves vary in terms of direction, type and magnitude (Feldman and Ng, 2007; Kornblum et al., 2018; Ng et al., 2007). They can encompass moving from one job to another within an organization, or moving between organizations, occupations, or career fields (Forrier et al., 2009). Moreover, throughout their career individuals can move between types of employment (e.g., working as an independent contractor, employee, or temporary agency worker) or forms of employment contract (e.g., temporary versus permanent). In the contemporary career context, also moves that cross the boundaries between a person's work and private life (e.g., when temporarily interrupting one's career to take care for children or relatives) are considered career transitions (Greenhaus and Kossek, 2014). Transitions may create minor or major interruptions in an individual's career (Gunz et al., 2007) and have varying implications for career sustainability (De Vos et al., 2019). Occupational changes are probably the strongest turning points of individuals' careers as they include a change of position and of employer (Dlouhy and Biemann, 2018; Feldman and Ng, 2007). Changes in employment type can be regarded as impactful as they have an impact on job security and financial aspects (e.g. social security implications when changing from working as an employee to freelancer (Tran et al., 2019)). Overall, career transitions imply mobility - a topic that is intrinsic to career research (Chudzikowski, 2012).

Employability is important for individuals throughout their career in order to acquire and retain work that is in line with their career needs, and as such it determines the options that individuals have for realizing desired career transitions over time within or outside their current job or position (Direnzo and Greenhaus, 2011; Van der Heijde and Van der Heijden, 2006). Initially, employability research mainly focused on school leavers and the unemployed, thereby addressing two key types of career transitions. The rapid socio-economic and technological changes leading to volatile labor markets and unpredictability of careers have made employability a permanent concern for individuals, organizations and policy makers (Direnzo and Greenhaus, 2011; Forrier et al., 2015; Savickas, 2011). As lifetime employment has been gradually replaced by the notion of lifelong employability (Forrier and Sels, 2003; Fugate et al., 2004; Hillage and Pollard, 1998; Rothwell and Arnold, 2007; Van der Heijden et al., 2009), lifelong learning and the transitions individuals make throughout their career have come to the forefront. Making career transitions can thereby provide opportunities for learning and development of competencies, thereby enhancing a person's employability - while at the same time the latter might be a prerequisite for making a transition. Thus, career transitions and employability are key elements in contemporary careers and are important for the sustainability of careers over time (De Vos et al., 2019; Heslin et al., 2019; Van der Heijden et al., 2019).

In the next sections, we will first provide a brief historical account of and key insights from research on employability and career transitions in their respective research fields. Next, we will take a conceptual view on the integration of both concepts and describe how the relationship between employability and career transitions has been studied in empirical research. We will conclude with implications and suggestions for future research.

\section{Career transitions}

Career transitions have always been central to the career literature (Wang and Wanberg, 2017). In their mapping of JVB article topics based on all JVB articles published between 1994 and 2016, Byington et al. (2019) found that career choice-referring to a broad range of career transitions, including the initial choice of an occupation, the transition between jobs or occupations and the transition to entrepreneurship_-was one of the five most prominent topic themes in this journal. Also Wang and Wanberg (2017), in their narrative review of 100 year applied psychology research on individual careers, identified career transitions as one of the five topical areas in the field. Although career transitions have received scholarly attention ever since Parsons (1909) wrote his seminal book "Choosing a vocation" (Wang and Wanberg, 2017), research on the topic has strongly intensified in the past thirty years because of the changing nature of careers (Forrier et al., 2009; Fouad and Kozlowski, 2019; McPherson, 2018). Since contemporary labor markets are faced with major economic (e.g., globalization) and technological changes (e.g., rise of artificial intelligence), it has become more challenging for individuals to achieve sustainable employment and accordingly, people are increasingly likely to change jobs, employers, and/or occupations multiple times throughout their career (McPherson, 2018; Sullivan and Baruch, 2009; Watts, 2005). Since career transitions are becoming more frequent (Chudzikowski, 2012), research interest in the topic has increased as well.

Both vocational psychologists and organizational psychologists have examined career transitions for around 100 years now (Hom et al., 2017; Wang and Wanberg, 2017). Although each field has its specific angles and cross-pollinations remain limited to date (Blustein et al., 2019; Fouad and Kozlowski, 2019), both fields went through some similar evolutions over the years.

In the early days (i.e., in the 1900s-1980s), vocational psychologists focused dominantly on understanding initial occupational choices-so dominantly school-to-work transitions-with the intent to help individuals make good career decisions and overcome career-decision making difficulties (Wang and Wanberg, 2017). Building on Parsons' insight that successful career choices require a good understanding of the self and the labor market, several interest inventories (e.g., Strong Vocational Interest Blanc, 1927; Holland Vocational Preference Inventory, 1958) and systematic job classifications (e.g., Dictionary of Occupational Titles, 1939) 
were developed. In addition, researchers theorized about and explored various factors that influence people's career choices, including the role of social learning, social-economic status, family, interests and personality (e.g., Krumboltz and Shapiro, 1979; Neiner and Owens, 1985; Super, 1957).

Early organizational psychologists were primarily concerned with understanding inter-organizational transitions-i.e., turnover. This focus was spurred by the longstanding awareness that employee turnover disrupts organizational functioning and therefore comes with a financial cost (Hom et al., 2017). Early turnover researchers (in the 1920s-1980s) mainly aimed to predict turnover. Many turnover studies built on March and Simon's (1958) model, which had introduced two key antecedents of turnover: desirability to move (generally operationalized as job dissatisfaction) and ease of movement (generally measured as perceived job opportunities, which highly resembles perceived employability). March and Simon's core insights reappeared in several other influential turnover models, such as Mobley's work (1977, 1979)—which introduced turnover intentions — and the comprehensive model of Steers and Mowday (1981). Together, these models inspired hundreds of studies on what precedes the specific career transition of inter-organizational job mobility.

Early vocational and organizational researchers thus dominantly explored antecedents of a few types of career transitions (i.e., school-to-work transitions in vocational psychology and inter-organizational transitions in organizational psychology). From the 1980s onwards, we noticed some new trends in both fields. For one, the changing nature of careers inspired researchers in both fields to broaden their focus. In vocational psychology, the awareness grew that not only students, but also adults can go through a career transition (Watts, 1996) and may therefore benefit from career counseling (Bernaud et al., 2006; Verbruggen and Sels, 2010). In organizational psychology, new concepts such as the 'boundaryless' and the 'protean' career spurred researchers to examine more different types of career transitions, including horizontal transitions (e.g., Chudzikowski, 2012), international assignments (e.g., Stahl et al., 2002), and portfolio work (e.g., Cohen and Mallon, 1999), and to explore not only objective but also psychological mobility (e.g., Forret et al., 2010; Verbruggen, 2012), i.e., people's attitudes towards crossing boundaries (Sullivan and Arthur, 2006).

Both fields also started to pay more attention to the phases after the career transition. In vocational psychology, both the original social-cognitive career theory (Lent et al., 1994) and later adaptations of this model (e.g., social cognitive model of well-being, Lent and Brown, 2006) were highly influential. These models did not only introduce novel social-cognitive antecedents of career choices (e.g., self-efficacy, outcome expectations), but also drew attention to potential outcomes, such as performance (Lent et al., 1994) and well-being (Lent and Brown, 2006). In organizational psychology, several studies started to examine the adjustment phase after (intra- and interorganizational) career transitions (Latack, 1984; Nicholson, 1984). These studies mainly applied a stress-coping perspective: career transitions are often stressful because they entail uncertainty and change, disrupt patterns and routines, and may threaten people's self-concept (Armstrong-Stassen, 2003; Moyle and Parkes, 1999; Pinder and Schroeder, 1987; West et al., 1987). Organizational psychology researchers also started to examine outcomes of career transitions, such the impact on organizational commitment, satisfaction and engagement (Gesthuizen and Dagevos, 2008; Kalleberg and Mastekaasa, 2001; Verbruggen et al., 2015).

Another novel trend in both vocational and organizational psychology is the emergence of nonlinear theories and studies (Blustein et al., 2019). For a long time, theoretical and empirical work on careers focused almost exclusively on linearity, i.e., on how people become aware of the option or need to make a career decision, then explore a number of alternatives, decide on the most suitable alternative, act on it and finally realize this decision (e.g., Gati and Asher, 2001; Griffeth and Hom, 1995; Lent et al., 1994; March and Simon, 1958; Mobley, 1977). However, desires and intentions to change often do not result in actual changes (Allen et al., 2005; Hom et al., 2012; Verbruggen and van Emmerik, 2018). This is because career decision and transition making is generally a highly complex process, influenced by myriad interrelated factors, including chance and unexpected events, and therefore hard to predict (Blustein et al., 2019; Pryor and Bright, 2011). In vocational psychology, this awareness gave rise to some novel theories, such as the chaos theory of careers (Pryor and Bright, 2011) and the systems theory framework (Patton and McMahon, 2014). In organizational psychology, various new concepts were launched to capture forms of non-linearity, such as career inaction (Verbruggen \& De Vos, 2020), reluctant stayers (Hom et al., 2012) and being locked-in (Stengard et al., 2016). In addition, several studies explored the consequences of these forms of non-linearity for people's behaviors and attitudes, for instance for their contra-productive work behaviors and career satisfaction (e.g., Burton et al., 2010; Mai et al., 2016; Verbruggen and van Emmerik, 2018).

\section{Employability}

Even though it might seem like a buzzword today, the term 'employability' goes back to the 1950s, when employability was conceived as an important determinant for securing paid work in the future (Feintuch, 1955). Until the 1980s, employability research mainly focused on unemployed persons and vulnerable groups on the labor market (Forrier et al., 2015), thereby mainly studying employability at the macro-level (e.g., impact of public policy on employment rate). Human capital was seen as the major determinant of employability, i.e., the development of skills and knowledge needed for entry in a given occupational field and for a predictable linear career path (De Vos et al., 2019). The topic was not yet on the agenda of vocational and organizational psychologists. With their major focus on youth entering the workforce (Swanson and Gore, 2000), vocational psychologists were mainly concerned with helping individuals understand their self and the labor market in view of making a good occupational choice that would lead to a stable career path afterwards (e.g., Holland, 1958; Krumboltz, 1979; Super, 1957). There was no interest in employability of employees having a paid job because, given the culture of job security and predictable career progress in most organizations, once someone had found a job the opportunity to stay employed was rather high (Magnum, 1976). In their study of volun- 
tary turnover, organizational psychologists, building on March and Simon's (1958) model, addressed the influence of perceived ease of movement yet without labeling it employability at that time (Direnzo and Greenhaus, 2011).

As from the 1980s employability research gradually broadened its focus in terms of target groups and possible determinants and became a topic of interest for both vocational and organizational psychologists. First, important changes in the labor market such as mass restructurings affected the job security of working individuals (Hall, 1976). In the first place those workers belonging to an organization's peripheral or external workforce (Atkinson, 1984) became vulnerable for layoffs and could no longer rely on the organization for securing their future (Barley and Kunda, 2006; O'Mahony and Bechky, 2006). But also for core workers the psychological contract centered around lifelong job security in return for loyalty and hard work gradually eroded due to increasing changes in working organizations (Arthur et al., 1999; Hall, 1976; Herriot and Pemberton, 1995). These evolutions led to individuals making more transitions during their career, and becoming more self-dependent for obtaining and retaining work, i.e., their employability (Thijssen et al., 2008). Spurred by these evolutions, vocational psychologists started focusing on how unemployed people could find and retain work during economic depressions or recessions (Swanson and Gore, 2000). Within organizational psychology, the idea that the 'career was dead' (Hall, 1976) led to a gradually increasing focus on the individual as the central actor in careers and on individuals' primary responsibility for their employability throughout their professional life (Arnold and Cohen, 2008; Forrier et al., 2018). This was reflected in so-called 'new career' concepts such as the protean career (Hall, 1976; Hall and Mirvis, 1996) and the boundaryless career (Arthur, 1994, 2014; Arthur and Rousseau, 1996). These concepts have in common that they have an optimistic focus upon the opportunities that self-dependence brings for developing a career that is fulfilling for people throughout their working life (Forrier et al., 2018) thereby conceiving the career as a sequence of learning experiences and opportunities for personal growth (Hall and Mirvis, 1996). With this broadened perspective upon employability of working individuals, researchers also started to study a wider range of possible determinants than only a person's knowledge and skills. Within vocational psychology, attention was given to job search competencies and counseling employees to help them make effective career decisions throughout the career (Fouad, 2007; Swanson and Gore, 2000). Within organizational psychology there was a growing interest in understanding the individual competencies needed for a successful self-driven career, thereby extending the narrow view on human capital to include a broader set of skills such as flexibility, networking, marketable skills, and continuous learning (Sullivan and Arthur, 2006). A general decrease in interest in the role of the organization in influencing employability could be observed in the career literature - with other research fields (mainly human resource management) addressing the challenges and potential costs the focus on employability implies for employers (De Vos and Dries, 2013).

The combination of rapidly increasing speed in technological developments, new business models, expanded globalization, and increased demands for productivity, creativity, and flexibility, has further stimulated the research interest in employability in the 21st century. In the field of vocational psychology, Savickas' introduction of career adaptability, defined as "readiness to cope with changing work and work conditions" (Savickas, 1994, p. 58) as a modification of Super's career maturity construct, signifies a shift in focus from understanding one's personal interests and strengths in view of obtaining satisfying work to the adaptive capacity individuals need for obtaining and retaining work throughout their career (Savickas, 2011). Career adaptability has given rise to a rich new field of career research that bridges the fields of vocational and organizational psychology (Fouad and Kozlowski, 2019).

Within organizational psychology there is a steady increase in research on the importance of employability for understanding individuals' careers, thereby also explicitly linking employability to career transitions (Eby et al., 2003; Forrier et al., 2015) and the influence of a broad set of competencies that are needed to stay employable (Forrier and Sels, 2003; Fugate et al., 2004; Van der Heijde and Van der Heijden, 2006). Compared to the initial view of employability as an individual's chances for getting and staying employed (Feintuch, 1955), current definitions more broadly refer to "the capacity of continuously fulfilling, acquiring or creating work through the optimal use of competences" (Van der Heijde and Van der Heijden, 2006, p. 453), or "the chance for employment on the internal or external labor market" (Forrier and Sels, 2003, p. 106). These definitions all imply the acquisition of employment within or outside the current organization, and with regard to future prospects (Van der Heijde and Van der Heijden, 2006).

Current employability research can be divided in input- and outcome-based approaches (Forrier et al., 2015, 2018). First, the input-based approach emphasizes aspects that increase the likelihood of obtaining and retaining a job, such as competencies or personal qualities (De Vos and Soens, 2008; Fugate et al., 2004; Koen et al., 2013; Peeters et al., 2019; Van der Heijde and Van der Heijden, 2006; van Harten et al., 2016). These are conceived as much broader than only functional expertise and include, for example, flexibility, adaptability, self-efficacy, self-awareness, and social capital. Forrier et al. (2009) have grouped these together under the label 'movement capital'. Second, the outcome-based approach focuses on outcomes that are associated with this likelihood of obtaining and retaining a job, such as self-perceived employability or the perceived chances to become employed in a job of one's preferences (see for instance Berntson et al., 2006; De Cuyper, Mäkikangas, et al., 2012; De Cuyper, Raeder, et al., 2012; Rothwell and Arnold, 2007; Vanhercke et al., 2014; Wittekind et al., 2010). Employability has also been conceived as an indicator of career success in that regard (Arnold and Cohen, 2008; Eby et al., 2003; Guan et al., 2019). Obviously, both types of employability approaches are important for understanding career transitions. Moreover, making career transitions, for instance internal and external job changes, are sometimes used as an indicator of employability (Forrier et al., 2015; Raemdonck et al., 2012).

Employability research has been criticized for being hardly theory driven (Forrier et al., 2018). Yet, both vocational and organizational psychology can bring relevant theoretical perspectives to further our understanding of employability. For instance social cognitive career theory (Lent et al., 1994) helps to explain how self-efficacy, defined as individuals' beliefs about their abilities to carry out actions to reach a specific goal, may affect a person's employability as it determines whether an action will be pursued, how much effort will be expended in carrying out that action, a person's persistence in the face of obstacles, and ultimate performance. Conservation of Resources theory (Hobfoll, 1989), a motivation and stress theory, has been used to understand the role 
of employability as a personal resource that helps individuals to stay resilient in terms of job loss or insecurity (e.g., De Cuyper, Raeder, et al., 2012) and that affects their wellbeing at work (Vanhercke et al., 2014).

\section{Career transitions and employability: integration}

The concepts of career transitions and employability are closely related and research on both addresses a common theme: the changes individuals make throughout their career (for career transition researchers: the type of career changes made; for employability researchers: employment opportunities and enactment of these opportunities), the factors explaining these changes and their consequences for the person. Hence, both address the core of what is defined as a career, i.e. the evolving sequence of work experiences throughout a person's working life (Arthur et al., 1989). Below, we provide a theoretical integration of the employability and career transitions literature by describing what both have in common in their conceptual and theoretical approaches.

\subsection{Conceptual overlap}

First, process models explaining career transitions and employability include overlapping mechanisms. In career transition models, perceived ease of movement—which highly resembles perceived external employability—is a mediating variable (e.g., Forrier et al., 2009; Steers and Mowday, 1981), thereby building on March and Simon's (1958) seminal work. Within employability literature, transitions are seen as indicator of a person's employability (e.g., Forrier et al., 2015; Raemdonck et al., 2012). For instance, the employability process model developed by Forrier and Sels (2003), integrating different conceptualizations of employability, defines individuals' labor market transitions as objective indicators of employability. Yet, most empirical work on employability and career transitions consider employability and transitions as distinct variables and address causal relationships between both rather than framing them as two concepts explaining the same phenomenon (Forrier et al., 2015).

Models explaining employability and career transitions also have in common that they both address the role of a person's movement capital. In the input-based approach to employability, employability is defined in terms of movement capital (e.g., Fugate and Kinicki, 2008; Van der Heijde and Van der Heijden, 2006) while the output-based approach, conceives it as a distinct variable explaining employability (e.g., De Cuyper, Mäkikangas, et al., 2012; De Cuyper, Raeder, et al., 2012; Vanhercke et al., 2014). The term movement capital was introduced in the turnover literature by Trevor (2001) and encompasses a person's skills, knowledge, competencies and attitudes that influence their opportunities for mobility (Forrier et al., 2009). In employability research, this is being studied in terms of employability-enhancing competencies (Van der Heijde and Van der Heijden, 2006), dispositions (Fugate and Kinicki, 2008), personal resources (De Cuyper, Mäkikangas, et al., 2012) and other individual differences (e.g., education, current job-related skills, and willingness to change jobs; Wittekind et al., 2010) (see also Forrier and Sels, 2003; Peeters et al., 2019). This relates to the broader emphasis career scholars place on the role of individual characteristics important for contemporary career success, such as career competencies (Akkermans et al., 2013; Defillippi and Arthur, 1994; Eby et al., 2003), adaptability (Savickas and Porfeli, 2012), or career resources (Hirschi, 2012).

\subsection{Agency versus structure}

Second, recent literature on both topics is characterized by a strong emphasis on the individual, consistent with the emphasis on agency in much of the recent careers literature. Fueled by new career concepts such as the boundaryless career (Arthur and Rousseau, 1996) and the protean career (Hall, 2004), much research has concentrated on mobile individuals who voluntarily build their careers across physical and psychological boundaries using career-relevant skills, with employability being a prerequisite for realizing career success (Forrier et al., 2009). Contextual elements (such as availability of jobs on the internal or external labor market) are mainly included as constraints reducing the likelihood of a career transition or turnover (Direnzo and Greenhaus, 2011). Overall, the employability literature addresses how employability benefits employees and the opportunities that changing employment relationships and the increased focus on individual agency may bring for them (De Vos and Soens, 2008). The underlying idea is that employability helps individuals to benefit from a volatile and competitive environment characterized by fast-changing and demanding job requirements (Eby et al., 2003).

\subsection{Focus on movement and change}

Third, in both research fields there is an emphasis upon movement and change yet with a different focus. Employability research focuses on the factors facilitating or hindering a person's sequence of job-related experiences, which is broader than transitions as these experiences can also accumulate while staying employed in the same job. Literature on career transitions is narrower in that it studies factors explaining transitions that take place on the internal or external labor market and what determines a successful transition (Ng et al., 2007), but pay less attention to transitions within jobs. The emphasis is upon the individual making a transition whereby antecedents of making a decision to change are studied and the type and magnitude of transition may bring along different challenges in view of successful adaptation. In employability research, given that much recent literature addresses perceived employability (cf supra), it is more about the opportunities for changing rather than the change itself, and upon the consequences of changes in the work context upon employability. 
There is only limited attention in both fields for the causes and consequences of lack of change. The concept of 'being locked in' in its recent modification by Stengard et al. (2017), combines low preference to stay in one's current job with lack of perceived opportunities to change (the latter referring to employability). Their research suggests negative implications for well-being among employees feeling locked in - suggesting that a lack of change may be related to negative consequences but the research addressing this topic is scarce.

\subsection{Objective versus subjective}

Both employability and career transitions have been examined using either objective or subjective indicators. Employability studies taking an objective approach examine indicators such as length of employment in the current job or with the current employer, number of promotions or duration of unemployment (e.g., Baum et al., 2008; Buckman et al., 2018; McArdle et al., 2007). Career transition research using objective indicators assess the number of career changes, whether career transitions are voluntary or involuntary, types of transition, magnitude of the transition, actual employee turnover (e.g., Chudzikowski, 2012; Dlouhy and Biemann, 2018; Forrier et al., 2015).

Both research fields also address subjective aspects of employability and career transitions. Many studies in the employability literature study self-perceived employability and how this perception of opportunities on the internal and external labor market is affected by individual and contextual factors, and how it relates to subsequent career decisions and outcomes (e.g., Berntson et al., 2006; Croucher et al., 2018; De Vos et al., 2011). This subjective component is also found in literature on career transitions with studies including intention to turnover, or measuring an individual's attitude towards making a career transition (e.g., psychological mobility, Forret et al., 2010; Verbruggen, 2012).

\section{Career transitions and employability: review of the literature}

As becomes clear from the above, employability and career transitions literature have much in common as shown among others in the overlap in core variables included in process models explaining employability and career transitions. In this section we further elaborate upon the relationship between both by reviewing empirical work addressing this relationship for working individuals, who are the central subjects in the 'new career' literature.

\subsection{Method followed}

In line with best practice (Short, 2009) we initially used Web of Science to identify peer-reviewed empirical articles for this literature review. We searched articles with the following combinations in their title, keywords or abstract that were published until December 2019: the combination of 'employability' and 'career mobility', 'career transition', 'job alternative', 'job mobility', 'job transition', 'turnover'. These articles were supplemented by essential records identified by the authors, like essential articles that didn't occur in our overview because of the search words that were used, for example some articles about 'employment opportunities'. After removal of duplicates, we found a total of 372 articles. Given that we chose to focus on career transitions as transitions in a working environment, we did not include a significant body of research which focuses on other types of transitions, for example school-to-work transitions or transitions encompassing retirement. This step left us with 118 articles focusing on working individuals.

Next, the three authors independently screened the downloaded core articles to decide whether they met the inclusion criteria, and consulted with one another as to whether to exclude certain articles. We did not include book chapters, unpublished papers or dissertations as we could not verify the quality of research given the lack of peer review. Articles with only an abstract in English or articles that were too applied to a specific context or workers' group were also excluded from the analysis, as well as conceptual papers. Our literature research left us with a total of 34 empirical studies for inclusion in our research. Table 1 gives an overview of the journals wherein two or more of these articles are published. As shown in this table, Journal of Vocational Behavior is by far the most frequently used outlet for research on the topic.

Interestingly, as shown in Fig. 1, the bulk of studies addressing the relationship between employability and transitions is quite recent and almost all of them are published after the year 2000. Probably the terminology used was somewhat different in the

Table 1

Overview of journals most prevalent in the literature review.

\begin{tabular}{ll}
\hline Journal & Amount of articles published from our review \\
\hline Journal of Vocational Behavior & 8 \\
Journal of Applied Psychology & 4 \\
European Journal of Work \& Organizational Psychology & 3 \\
Journal of Psychology & 2 \\
Career Development International & 2 \\
Personnel Review & 2 \\
\hline
\end{tabular}




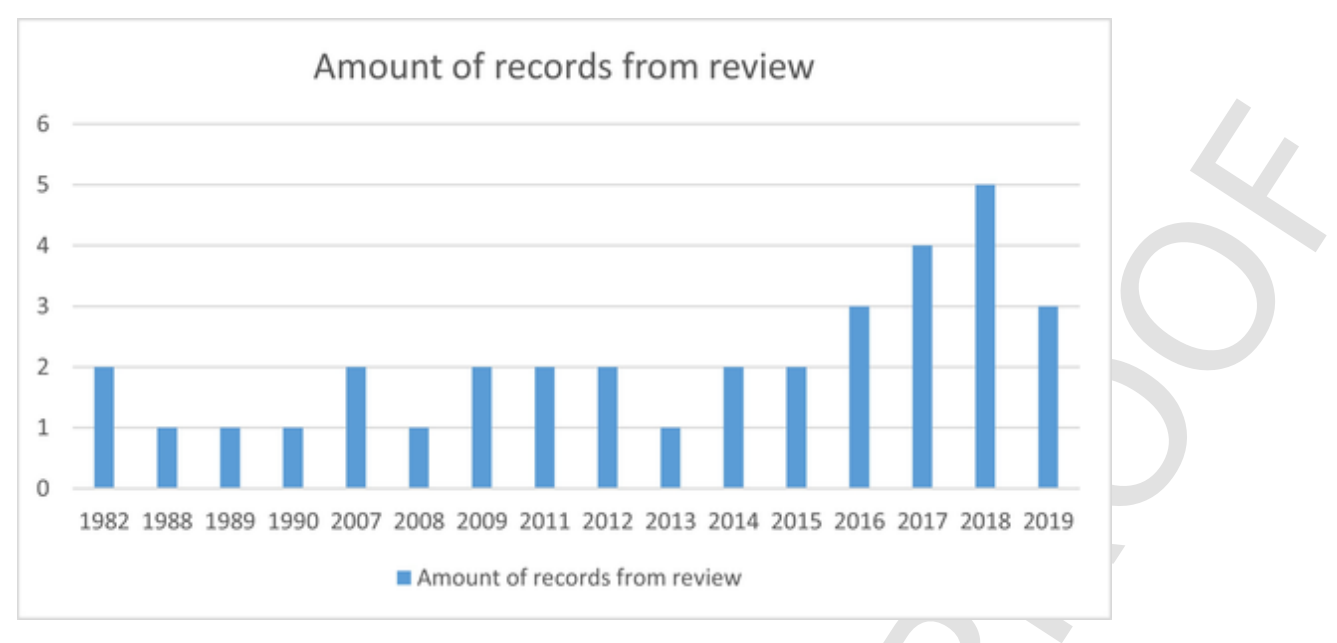

Fig. 1. Overview of articles by publication year.

early years, for example 'perceived job alternatives' or 'perceived employment opportunities', and as such they are not included in this review.

In the next sections we go more in-depth into our literature review. We first describe the major findings from studies conceiving employability as an antecedent of career transitions. Second, we review the articles wherein career transitions are treated as antecedent of employability. Next, studies addressing the bi-directional relationship between both concepts are reviewed, followed by those studies addressing psychological mobility.

\subsection{Employability as antecedent of career transitions}

The large majority of studies in our review consider employability as important for individuals in order to acquire and retain work that is in line with their career needs, and as such it is theorized to determine the options that individuals have for realizing desired career transitions over time. This is reflected in empirical designs studying employability as an antecedent of career transitions. Most of this research focuses on the relationship between perceived external employability and (intention to) turnover. The main idea behind these studies is that the more alternatives people perceive on the external labor market, the more likely it is that they will leave their organization. Early studies on this topic (e.g., Arnold and Feldman, 1982; Griffeth and Hom, 1988; Michaels and Spector, 1982) build on March and Simon (1958) and, hence, used labels like 'perceived ease of movement' or 'perceived employment alternatives' as indicator of employability. More recent studies on this relationship are more often situated in the employability literature and, accordingly, use concepts like perceived employability (e.g., Nelissen et al., 2017).

Although most studies found support for perceived alternatives to trigger turnover (intentions) (e.g., De Cuyper et al., 2011; Nelissen et al., 2017), some did not find a significant relationship (e.g., Mitchell et al., 2001). These mixed results have stimulated researchers to examine moderating variables affecting the relationship between employability and turnover. This research found that employees who perceive themselves as highly employable are more likely to have turnover intentions or to actually leave their employer in case of low affective commitment (Acikgoz et al., 2016), high perceived job security (Acikgoz et al., 2016), low job control (De Cuyper et al., 2011), and low perceived career opportunities (Lu et al., 2016), among others. Other studies have addressed perceived employability as a moderator explaining when other variables lead to turnover (intentions). For example, Wheeler et al. (2007) found that perceived job mobility moderated the job satisfaction-intent to turnover relationship such that this relationship is stronger when perceived job mobility is high versus low. Swider et al. (2011) found evidence for a moderating role of perceived job alternatives in the relationship between job search and turnover.

While most studies relating employability to turnover (intentions) focus on perceived employability, some studies also include other indicators of employability, such as employability-enhancing activities or occupational expertise. In these studies, employability is often framed as a potential risk for employers, thereby referring to the so-called management paradox (De Cuyper and De Witte, 2011), stating that development activities enhancing employees' employability also increase the risk for employee turnover. Therefore, employers may be reluctant to invest in employability-enhancing activities. On the other hand, development activities are considered to be important for employee performance and retention (see for instance the literature on high performance work systems; Takeuchi et al., 2009). Research suggests there is something to say for both pathways (e.g., De Vos et al., 2017; Nelissen et al., 2017). For instance, Nelissen et al. (2017) found that while employee development may increase the likelihood of turnover by increasing perceived external employability (i.e. perceived job alternatives with other employers), it may reduce turnover via perceived internal employability (i.e. perceived job alternatives with the current employer). Moreover, results from this study suggest that factors such as type of development initiative (Nelissen et al., 2017) matter. Comparable results were obtained in a cross-sectional study by De Vos et al. (2017) who found that occupational expertise (an indicator of movement capital) was associated with job search intensity through perceived internal and external employability. Perceived internal employability negatively medi- 
ated the relationship between occupational expertise and job search intensity, while there was a positive mediational effect of perceived external employability.

Finally, a few studies examining employability as an antecedent of mobility have focused on other transitions than turnover, such as industrial and occupational boundary crossing. For example, Kornblum et al. (2018) studied the influence of two indicators of employability - education level and openness to experience - together with labor market conditions, on career mobility. They found that level of education had a positive effect on organizational and industrial boundary crossing, and changes in the labor market were related to organizational boundary crossing, while openness to experience had no effect on career mobility. None of the predictors were related to occupational boundary crossing.

All in all, the available research suggests that employability generally increases the likelihood of career transitions: employees with high employability are more likely to leave their current organization, and sometimes even industries. The relationship is buffered when employees feel satisfied or committed in their current job, when they perceive high job control or opportunities for internal career development. The latter is also confirmed by studies including both perceived internal and external employability, with the former decreasing the likelihood of (intention to) turnover. Our review did not show evidence, however, for the influence upon other types of transitions.

When overlooking the studies on employability as antecedents of job mobility, it is notable that the large majority of these studies focuses on perceived employability as (a subjective) indicator of employability and on (intent to) turnover as the type of job mobility. Other indicators of employability and mobility are rare. In addition, although several studies on this relationship use two-wave designs in which transitions are assessed at T2, research was rarely truly longitudinal in nature, i.e., measuring similar concepts at different moments in time. As such, we know little about how, for instance, changes in employability affect the process of making a career transition over time. Moreover, most research is based upon single source, perceptual data with only few studies including actual turnover data - thereby limiting the conclusions we can draw regarding actual career transitions.

\subsection{Career transitions as antecedent of employability}

Studying career transitions may also help to understand employability. As career transitions create new experiences for individuals, this enables them to develop new competencies, which may enhance their movement capital (Forrier et al., 2009, 2015). These competencies can be job-specific, but successfully making a transition also requires transferable skills such as adaptability, flexibility, or networking (Clarke, 2008; Forrier et al., 2009). In contrast with the studies reported above, there is only a minority of studies addressing this direction of the relationship between career transitions and employability, and findings seem to depend on the type of career transition being studied. Moreover, the outcomes studied as indicators of employability are rather diverse.

The idea that career transitions enhance employability fits with career theories taking an agentic perspective on careers and is particularly prevalent in the boundaryless career model (Arthur and Rousseau, 1996). The central tenet of this model is that the changes in work roles and environments encountered through career mobility provide opportunities to develop new job-related competencies as well as a broader set of career competencies enabling future employability. (Arthur and Rousseau, 1996). Yet, other voices point to the potential negative consequences of career transitions for employability when one's current skill set does not transfer to the new work role (e.g., Gesthuizen and Dagevos, 2008). Guan et al. (2019) recently reviewed empirical studies addressing the relationship between career boundarylessness and career success and included employability as a possible mediator of this relationship. Their review included 61 studies addressing psychological or physical mobility, and voluntary as well as involuntary transitions Overall the conclusion of this review is that boundaryless careers have mixed effects on career success, depending on various individual and contextual factors. When zooming in on those studies addressing the impact of (indicators of) employability, evidence is rather positive. For example, Guan et al. (2019) report a positive association between having a variety of roles and responsibilities during one's career and strategic thinking competency among executives (Dragoni et al., 2011), and for a positive relationship between career boundarylessness and career competencies (Colakoglu, 2011; Stumpf, 2014) as well as career adaptability and competencies (Guan et al., 2016).

Thus, transitions may be beneficial for enhancing an individual's employability, yet the studies reported above all addressed voluntary career transitions. Less is known about when and how involuntary transitions may enhance employability, or what might be the impact moderating role of transition type (e.g., job, organizational or occupational) or direction (e.g. promotion versus demotion).

Within the so-called 'new career' literature, studies have addressed psychological mobility as antecedent of employability. Boundaryless mindset has been found to be positively related to unemployed adults' employability (McArdle et al., 2007). Kirves et al. (2014) found that employees' perceptions of their opportunities for residential mobility (move to another place because of a new job) - so another type of psychological mobility - was positively associated with perceived employability. These studies thus suggest that a mindset of psychological mobility - and thus openness for career transitions - is positively associated with employability. Again, these findings should be interpreted considering the type of employability being studied. In a five-wave longitudinal study addressing perceived chances for upward mobility among Norwegian workers, Bernstrom et al. (2019) found that employees with higher perceived chances for upward mobility and those with higher education levels had a significantly lower preference for job security which might be considered as the counterpart of preference for transitions.

While much of the research in our review is quantitative, Clarke (2008) adds additional insights based upon a qualitative study consisting of in-depth interviews with managers going through a career transition program. These interviews revealed that individuals differed in the extent to which they had a traditional versus boundaryless or protean career. This was reflected in behaviors sup- 
portive of future employability (lifelong learning, flexibility, career planning) among the latter group as opposed to behaviors more in line with traditional careers (short-term focus on current job requirements, development of organization or industry specific skills) among the former group. Those individuals with experience across a range of roles and organizations, as well as a focus on developing themselves for the future, were more confident in their employability and more optimistic about the future.

In the studies reported here, employability has been operationalized in different ways. While some studies capture individuals perceptions of their opportunities on the labor market (e.g., Clarke, 2008), other studies assessed employability in terms of job-related or generic knowledge or skills (e.g., Dragoni et al., 2011). In our review, we limited our selection of studies to those explicitly conceptualizing the latter in terms of employability or "movement capital". The findings reported here all point to the relevance of making career transitions for strengthening one's movement capital. A further exploration of the literature on training and development may provide additional insights to understand when and how transitions provide a learning context for individuals that enables them to develop new competencies that contribute to their employability.

As we noticed already in the previous section, also the studies addressing the relationship between transitions and employability are rarely longitudinal, with designs allowing to address changes in employability over time as a consequence of career transitions. Therefore, insights into the process of how employability develops over time, influenced by career transitions, remains limited. Again, transitions are often measured in terms of psychological mobility rather than actual mobility, which also limits the conclusions one can draw regarding whether and under which conductions actual career transitions enhance employability.

\subsection{Bi-directional relationship between employability and career transitions}

While most theoretical models on turnover mainly focus upon the antecedents explaining turnover (and the possible role of employability therein), employability is mostly theorized as a process consisting of a cycle or dynamic chain of recurring relationships between employability and transitions (Forrier et al., 2015; Forrier and Sels, 2003). Also theoretical models taking a broader perspective upon mobility (broader than turnover) propose such a cyclical process in which employability may explain transitions, which in turn have implications for employability (Forrier et al., 2009). Obviously, these process models all include an element of time. Yet, perhaps because of the latter, the empirical evidence for these relationships is limited although available studies provide some interesting insights. Forrier et al. (2015) using a two-wave study found that job transitions promote employees' movement capital, which then affects perceived employability and ultimately feeds back to job transitions. Furthermore, they found that past external but not internal job transitions were positively related to movement capital. Perceived external employability related positively to external transitions over time, while perceived internal employability related positively both to external and internal transitions over time. Both internal and external transitions were positively related to movement capital. Although this study is not truly longitudinal in that not all were repeated measures and there were only two data collection waves, the results are interesting in that they show how the relationship between employability and transitions works in multiple directions and that it is thereby important to consider both the internal and external labor market in terms of transitions and employability.

Dlouhy and Biemann (2018) studied the implications of occupational transitions for human capital among German workers during the first 15 years of their career. Using path dependency as an explanatory framework, these authors theorized and found that working in a certain occupation leads to an increase in human capital over time. When more occupation-specific skills and knowledge are obtained, the opportunity costs of an occupational change increase and the occupational career becomes increasingly locked in, thereby decreasing the likelihood of occupational transitions. Thus, while occupational seniority leads to increased employability in terms of occupation-specific knowledge and skills, it also reduces the development of a broader skillset and therefore lowers the likelihood of transitioning to another occupation. These two studies suggest that career transitions and employability are mutually related over time, but that the type of transition may matter in predicting whether employability may stimulate individuals to engage in future career transitions or leads to a lack of change over time. Moreover, it seems to be important to specify the scope of employability: whether it concerns employability in the current job or organization versus employability on the broader labor market. To further our insights, it is also needed that appropriate research designs are being used that capture the interrelatedness of both over time. Again, our review and the limited number of studies capturing this process perspective, points out the need for future research to validate available findings and address the issues mentioned here.

\section{Discussion and pathways for future research}

Overall, our review of the empirical literature addressing the relationship between career transitions and employability supports the idea that both concepts are strongly related: employability helps to explain the transitions employees make during their career, while transitions are beneficial for employees' employability. As such they support the idea that transitions are a recurring issue throughout the career and that individuals' movement capital, opportunities for change and actual transitions form a dynamic chain (Forrier et al., 2015). These findings align with the central tenet of sustainable careers literature, namely that individuals continuously affect their career potential through the opportunities they encounter, the choices they make, and the learning cycles they go through (De Vos et al., 2019; Van der Heijden and De Vos, 2015). The individual's career potential, in turn, affects subsequent career opportunities and its sustainability over time.

While the findings reported above might not be surprising given the longstanding and rich research tradition in both fields, what's maybe more important, in our view, is to consider what's left out of scope in current work on the relationship between both. In what follows, we elaborate on the most pertinent observations in that regard, i.e. (1) the discrepancy between the breadth 
of both concepts and how they are empirically being studied, (2) the over-emphasis on the individual and lack of attention for the role of the organization, (3) the focus on linearity, and (4) the limited attention for time. We end with some opportunities we see for bridging the fields of vocational and organizational psychology in view of furthering our understanding of the dynamics of career transitions and employability across the career.

\subsection{Career transitions and employability: broad concepts versus narrow study focus}

In essence, career mobility implies the transition from one position to another and these transitions can take many forms including change of jobs, organizations, occupations or a combination (Chudzikowski, 2012; Feldman and Ng, 2007; Forrier et al., 2009). Moreover, they can differ in direction and imply a lateral, upward or downward move (Ng et al., 2007). Following the literature taking a work-home perspective on careers (Greenhaus and Kossek, 2014), even transitions between work and other life domains throughout the career might be considered a transition. This is in sharp contrast with the findings from our literature review where the vast majority of articles study transitions by measuring (intention to) turnover.

The same holds for employability research which does not reflect the breadth of the concept referring to people's (perceived) chances for obtaining and retaining work (Forrier et al., 2009; Rothwell and Arnold, 2007; Thijssen et al., 2008; Vanhercke et al., 2014). Most of the research studying employability from an output-based perspective addresses (perceived) opportunities to change while there is little or no attention for the (perceived) opportunities to keep one's current job. Even the term movement capital might be misleading in that regard, as it suggests that employability is about changing jobs and not (also) about keeping one's current job (Peeters et al., 2019).

In part, this observation can be explained by the breadth of both concepts. Because they are so broad in scope, the risk exists that both are used as umbrella terms and that more specific concepts are used to study particular types of transitions (e.g. promotion, demotion, occupational change), or employability (e.g., being locked in); a criticism that is being raised in the literature for several years now (e.g., Forrier et al., 2015, 2018; Forrier and Sels, 2003; Peeters et al., 2019). This also became apparent during our literature review. On the one hand, further inspection of the studies we initially found using our key words revealed that (one or both) of our key terms were only used in the introduction or discussion to position the research in the field of contemporary careers but did not really address employability or career transitions. On the other hand, several other studies that did not result from the systematic search were added as they did study employability in relationship with transitions yet using different labels (e.g., Carless and Arnup, 2011; Equeter et al., 2018; Guan et al., 2016; Wheeler et al., 2007). This was especially apparent when considering the input-based conceptualization of employability (Forrier et al., 2009). Several studies in our review measure employability via indicators of movement capital (e.g., Forrier et al., 2015 included among others education and adaptability as indicators over movement capital) while other studies that did not turn up in our review, study the same indicators without labeling it employability (e.g., Haibo et al., 2018, studied the role of adaptability; Kornblum et al., 2018, studied the influence of education and openness to experience). Obviously this limits the accumulation of knowledge on the topic and may also limit potential integration of insights from vocational and organizational psychology literature.

\subsubsection{Broadening the perspective upon employability}

To move the field further, future researchers could do a meta-analysis departing from a clear conceptualization and typology of indicators of employability in relationship with different types of career transitions. This would allow for a more systematic search and grounded criteria for including studies in the analysis such that sound conclusions can be drawn about the strengths, directions and conditions explaining the relationships by bringing together a wider range of studies on this topic.

\subsubsection{Broadening the types of research populations studied}

The research populations included in our review are working individuals - yet almost all studies we found address transitions between organizations or occupations with very limited research on employability in relationship with transitions to other types of employment. However, the employment relationship is only one of many ways in which individuals can work for organizations (Barley et al., 2017; Tran et al., 2019). Some studies have addressed the employability of workers in precarious employment (Håkansson and Isidorsson, 2015) or the employability of freelancers (LoPresti et al., 2018) but this stream of research is still limited and does not relate employability to career transitions. Interesting research questions here are whether employability affects individuals' choices for a transition from standard employment to an alternative, employer-independent form of work such as freelancing or entrepreneurship (see also Burton et al., 2016), what are potential push or pull motives, what explains a successful transition, and how employability is enhanced through enacting a non-standard career form including multiple short-term (parallel or sequential) assignments for different organizations.

\subsection{Person-centric focus and limited consideration of context}

A common thread in the studies in our review is their focus on the individual as the level of analysis. What becomes clear from these studies is that many of them implicitly or explicitly build on the 'new career' paradigm (Arthur and Rousseau, 1996; Arthur et al., 1999; Hall and Mirvis, 1996) in which the employee stands on the forefront while the organization, seen as the context within and across which careers unfold, stays at the background and is often not addressed (Forrier et al., 2018). It also not surprising given the tradition in vocational psychology to focus on the individual's career (Fouad and Kozlowski, 2019; Savickas, 2011) 
Yet, this is also an important omission that may limit our understanding of how employability is related to career transitions in several ways. First, career transitions on the internal labor market are often not considered although also mobility on the internal labor market is a type of career transition (e.g. forms of horizontal or vertical mobility; $\mathrm{Ng}$ et al., 2007). While this focus has increased our understanding of what explains employees' external mobility, it also limits our thinking especially given that most employees still spend long periods with the same employer (Rodrigues and Guest, 2010). Second, organizational practices do play an important role in employees' internal and external employability (see for instance the literature on the role of training and development in explaining employability (e.g., Benson, 2006; De Vos et al., 2011; Veld et al., 2015)) as well as their decisions to move on the internal or external labor market (see for instance the literature on the importance of organizational career management for employee retention, (e.g., Armstrong-Stassen and Ursel, 2009; Kraimer et al., 2011)). This is also supported by two studies in our review showing that organizational career management practices affect career mobility decisions via both internal and external employability perceptions (Nelissen et al., 2017) and that internal career opportunities may buffer the positive relationship between perceived external employability and turnover intentions (Lu et al., 2016). Yet, further research is needed to understand the role of the organizational context. Future research might address, for example, how career experiences within organizations, e.g. career management practices such as temporary project work, lateral moves, or job enrichment, but also individual practices such as job crafting or i-deal negotiation may affect an individual's employability, future career decisions, and the relationship between both.

Moreover, today's volatile work context implies that jobs are no longer a stable composition of tasks requiring a predictable set of skills in order to perform (Van der Heijde and Van der Heijden, 2006). It is therefore not only interesting to study employability in relationship with transitions individuals make, but also investigate employability in relationship with transitions occurring within the job. Having a high job or occupational tenure does not necessarily mean that a person will always need the same skillset in order to stay employable; with jobs changing rapidly due to technological evolutions, the lifecycle of competencies needed for successful performance in the job is shortening rapidly (De Vos et al., 2019; Thijssen et al., 2008; Van der Heijde and Van der Heijden, 2006). Thus, the divide between job-specific competencies or occupational expertise being important for staying employable in the current job versus the need for a broader set of competencies for being able to move (cf. movement capital, Forrier et al., 2009) may no longer hold. With rapid changes also occurring within jobs, this might also increase the importance of employability-enhancing competencies such as adaptability or flexibility (Van der Heijde and Van der Heijden, 2006), or what Peeters et al. (2019) recently have called 'employability capital', for keeping pace with these changes. Therefore, future research could further address the impact of changes such as digitization and how this affects not only employability but also individuals' career changes.

\subsection{Linearity focus}

Most research on employability and career transitions so far has focused on linearity and consistency. That is, these studies tend to think about and study employability and career transitions in a largely chain-like linear way. For instance, employability studies often examine how employability investments enhance people's employability competences, which in turn increase their perceptions of being employable, which may then result in a new job (e.g., De Vos et al., 2011; Forrier et al., 2015; Forrier and Sels, 2003). Similarly, theories and empirical studies on career transitions focus on how people who became aware of the option or need to make a career decision formulate a change intention, explore a number of alternatives, decide on the most suitable alternative, act on it and then realize this decision (e.g., Gati and Asher, 2001; Griffeth and Hom, 1995; Lent et al., 1994; March and Simon, 1958; Mobley, 1977; Van Esbroeck et al., 2005). The focus on linearity and consistency is also apparent in the analytical techniques that are used in these literatures, which are dominantly regression-based (e.g., multivariate regressions, SEM) and focus on how one variable on average relates to another variable. However, overall, these linear, regression-based models tend to have limited exploratory power, with $\mathrm{R}^{2}$ s of $15 \%$ at most (e.g., Berntson et al., 2006; De Vos et al., 2011; Veld et al., 2015).

Due to the dominance of linear models and regression-based techniques, we know little about deviations from the average relationship or the consequences of such deviations. For instance, why don't people experience more perceived employability after following a training or receiving performance feedback (e.g., Akkermans et al., 2019; Nelissen et al., 2017)? And what are the consequences when a person who made an external job transition does not experience more employability competencies after the transition, even though the average employee in this situation does so (Forrier et al., 2015)? As Van Maanen suggested already in 1977, the crucial factor in understanding careers (and by extension: employability) may lie precisely in understanding deviation from the average relationship. Examining deviations from the average relationship may largely enhance our understanding of core employability and transition concepts. For instance, understanding why two people with similar competencies have different employability perceptions will help us learn more about the meaning of perceived employability. In addition, examining these deviations may also shed light on different paths that can follow from a particular starting state or, conversely, different paths that lead to the same end state. For instance, a desire to change can be followed by taking action, which in turn is followed by realizing the desired change, but it is also possible that people do not take sufficient action or take action but encounter external barriers that inhibit the change to happen (i.e. multifinality; Verbruggen \& De Vos, 2020). Similarly, different events and reasons have been found to lead to turnover (e.g., Maertz and Kmitta, 2012). Shedding light on different pathways can help to more fully understand a specific phenomenon.

Stepping away from the chainlike linear way of thinking may also trigger researchers to examine novel ways in which employability and career transitions are related. Our review revealed that most studies that include both concepts model perceived employability as an antecedent of making a career transition (most often: turnover), or vice versa, i.e., career transitions as antecedent of employability. Recently, however, research has shown that looking at interaction of both variables is meaningful as well. In particu- 
lar, research on the locked-in phenomenon showed that employees who did not make a transition and experienced low employability reported lower subjective health and more depressive symptoms (Stengard et al., 2016) compared to those who were not locked-in. It could be interesting for future research to look at other - and perhaps more complex - combinations as well. For instance, what if people are unhappy in their job, perceive high employability but do not change jobs? This might be a case of career inaction, which, according to Verbruggen \& De Vos, 2020, is at risk of lower well-being as well.

\subsection{Role of time}

Even though the concept of careers is inherently dynamic in nature, the way in which time has been incorporated in empirical studies is rather limited. This is an ongoing concern in career research (Fouad and Kozlowski, 2019) that is being confirmed in our literature review with most studies using a cross-sectional design. Both factors within the person and within their context change over time, and may affect the choices individuals make to stay in the same job or make a career transition, or to participate in development activities that broaden their competencies or increase their current expertise. Together the accumulation of decisions people make may positively or negatively impact their future opportunities thereby affecting the sustainability of their career over time (De Vos et al., 2019; Heslin et al., 2019). Longitudinal research designs are imperative to answer questions such as whether, when and how career transitions trigger change in people's employability competences and perceptions and if so, how durable this change is. Both changes within the person and within the context are important to consider in that regard. Think, for instance, of the consequences of technological changes for employees' employability and career transitions.

Conceptualizing the element of time will also be important in future research. For instance, time can be conceived as linear or cyclical time, with linear time referring to careers as a set of stages and the cyclical view arguing that careers can exist of multiple sequences of stages that restart when taking a new job for instance (Mirvis and Hall, 1994). Understanding the impact of time in people's sensemaking processes regarding their career will also be important. People understand their current and orient their future selves through an interplay of past and current events, which is referred to as temporality (Schultz and Hernes, 2012). Finally, considering time is important to understand the interplay of periods of stability and change, as people often hold a steady position over time and use their current jobs as reference point for career changes, making the distinction between jobs and careers blurry (Hall and Las Heras, 2010). Investigating both periods of stability and change will help to further our understanding of employability as a person's change for obtaining and keeping a job (Nagy et al., 2018).

Not only other research designs, but also other analytic methods may be necessary if we want to better capture time in career and employability research. For instance, optimal matching procedures could be used to find patterns in people's career paths over time (e.g., Biemann et al., 2012; Kovalenko and Mortelmans, 2014). Also latent growth models could be interesting to examine how, for instance, perceived employability changes over time. Applying a dynamic systems perspective, i.e., an integrated approach wherein context and temporal processes are taken into account simultaneously (Kozlowski et al., 2013; Vantilborgh et al., 2018; Wang et al., 2016) can also be an innovative method as it investigates the rules that govern the change, regulation and maintenance of states within the same person (Wang et al., 2016), whereby change can be caused by external variables or by its previous state.

\subsection{Bridging vocational and organizational psychology}

We conclude with some final reflections on the perspectives of vocational and organizational psychology upon the relationship between career transitions and employability. As discussed earlier in this paper, both topics are a central focus in both disciplines although both have been looking at them from different angles. While career transitions have always been at the core of vocational psychology, with a gradual broadening of focus from occupational entry and unemployed people to include the careers of all working individuals, they have also been an area of interest for organizational psychology researchers with an evolution in focus from explaining organizational turnover to attention for a broader range of career transitions putting the individual at the forefront. On the other hand, the research interest for employability by both vocational and organizational psychology researchers is relatively younger. It coincides with the growing interest in career choices as a recurring issue throughout the lifespan within vocational psychology and the focus on individual agency in careers within organizational psychology since the 1980s. The strong increase in studies addressing the relationship between career transitions and employability in the 21st century provides opportunities for further integrating insights from both disciplines. This is already the case for career adaptability (Savickas, 1994), which is core in many conceptualizations of employability and in explaining successful career transitions. In the same vein, social cognitive career theory (Lent and Brown, 2006) can provide further theoretical ground for understanding the process of how employability and career transitions relate over time, as individuals prepare for and cope with change throughout their career. Inversely, organizational psychology can help to contextualize future research by addressing the role of the employment relationship, job characteristics, organizational practices and relationships in the work setting and their interaction with individual career attitudes, to name just a few.

Finally, the longitudinal research designs and data-analytical techniques aimed at explaining turnover have a long history in turnover literature, may inspire future research in vocational psychology to study the bi-directional relationship between career transitions and employability over time.

In all, we hope that this paper inspires career scholars to widen their perspective upon and learn from the seminal work in both organizational and vocational psychology to increase our understanding of careers and employability in their future research projects. 


\section{Uncited references}

\section{Declaration of competing interest}

The authors declare that they have no known competing financial interests or personal relationships that could have appeared to influence the work reported in this paper.

\section{References}

Acikgoz, Y, Sumer, H C, \& Sumer, N (2016). Do employees leave just because they can? Examining the perceived employability-turnover intentions relationship. Journal of Psychology, 150(5), 666-683. doi:10.1080/00223980.2016.1160023.

Akkermans, J, Brenninkmeijer, V, Huibers, M, \& Blonk, R W B (2013). Competencies for the contemporary career: Development and preliminary validation of the career competencies questionnaire. Journal of Career Development, 40(3), 245-267. doi:10.1177/0894845312467501.

Akkermans, J, Tims, M, Beijer, S, \& De Cuyper, N (2019). Should employers invest in employability? Examining employability as a mediator in the HRM - Commitment relationship. Frontiers in Psychology, 10. doi:10.3389/fpsyg.2019.00717.

Allen, D G, Weeks, K P, \& Moffitt, K R (2005). Turnover intentions and voluntary turnover: The moderating roles of self-monitoring, locus of control, proactive personality, and risk aversion. Journal of Applied Psychology, 90(5), 980-990. doi:10.1037/0021-9010.90.5.980.

Armstrong-Stassen, M (2003). Job transfer during organizational downsizing: A comparison of promotion and lateral transfers. Group \& Organization Management, 28(3), 392-415. doi:10.1177/1059601102250824.

Armstrong-Stassen, M, \& Ursel, N D (2009). Perceived organizational support, career satisfaction, and the retention of older workers. Journal of Occupational and Organizational Psychology, 82(1), 201-220. doi:10.1348/096317908X288838.

Arnold, H J, \& Feldman, D C (1982). A multivariate analysis of the determinants of job turnover. Journal of Applied Psychology, 67(3), 350-360. doi:10.1037/ 0021-9010.67.3.350.

Arnold, J, \& Cohen, L (2008). The psychology of careers in industrial and organizational settings: A critical but appreciative analysis. International Review of Industrial and Organizational Psychology, 23(1).

Arthur, M (2014). The boundaryless career at 20: Where do we stand, and where can we go? Career Development International, 19(6), 627-640. doi:10.1108/ CDI-05-2014-0068.

Arthur, M, Inkson, K, \& Pringle, J (1999). The new careers: Individual action and economic change. SAGE.

Arthur, M B (1994). The boundaryless career: A new perspective for organizational inquiry. Journal of Organizational Behavior, 15(4), 295-306. doi:10.1002/ job.4030150402.

Arthur, M B, Hall, D T, \& Lawrence, B S (1989). Handbook of career theory. Cambridge University Press.

Arthur, M B, \& Rousseau, D M (1996). A career lexicon for the 21st century. Academy of Management Perspectives, 10(4), 28-39. doi:10.5465/ame.1996.3145317.

Atkinson, J (1984). Manpower strategies for flexible organisations. Personnel Management, 16(8), 28-31.

Barley, S R, Bechky, B A, \& Milliken, F J (2017). The changing nature of work: Careers, identities, and work lives in the 21st century. Academy of Management Discoveries, 3(2), 111-115. doi:10.5465/amd.2017.0034.

Barley, S R, \& Kunda, G (2006). Contracting: A new form of professional practice. Academy of Management Perspectives, 20(1), 45-66. doi:10.5465/ amp.2006.19873409.

Baum, S, Bill, A, \& Mitchell, W (2008). Unemployment in Non-Metropolitan Australia: Integrating geography, social and individual contexts. Australian Geographer, 39(2), 193-210. doi:10.1080/00049180802056856.

Benson, G S (2006). Employee development, commitment and intention to turnover: A test of "employability" policies in action. Human Resource Management Journal, 16(2), 173-192. doi:10.1111/j.1748-8583.2006.00011.x.

Bernaud, J-L, Gaudron, J-P, \& Lemoine, C (2006). Effects of career counseling on French adults: An experimental study. The Career Development Quarterly, 54(3), 242-255. doi:10.1002/j.2161-0045.2006.tb00155.x.

Bernstrom, V H, Drange, I, \& Mamelund, S-E (2019). Employability as an alternative to job security. Personnel Review, 48(1), 234-248. doi:10.1108/PR-09-2017-0279.

Berntson, E, Sverke, M, \& Marklund, S (2006). Predicting perceived employability: Human capital or labour market opportunities? Economic and Industrial Democracy, 27(2), 223-244. doi:10.1177/0143831X06063098.

Biemann, T, Zacher, H, \& Feldman, D C (2012). Career patterns: A twenty-year panel study. Journal of Vocational Behavior, 81(2), 159-170. doi:10.1016/ j.jvb.2012.06.003.

Blustein, D L, Ali, S R, \& Flores, L Y (2019). Vocational psychology: Expanding the vision and enhancing the impact. The Counseling Psychologist, 47(2), 166-221. doi:10.1177/0011000019861213.

Buckman, D G, Johnson, A D, \& Alexander, D L (2018). Internal vs external promotion: Advancement of teachers to administrators. Journal of Educational Administration, 56(1), 33-49. doi:10.1108/JEA-01-2017-0003.

Burton, J P, Holtom, B C, Sablynski, C J, Mitchell, T R, \& Lee, T W (2010). The buffering effects of job embeddedness on negative shocks. Journal of Vocational Behavior, 76(1), 42-51. doi:10.1016/j.jvb.2009.06.006.

Burton, M D, Sørensen, J B, \& Dobrev, S D (2016). A careers perspective on entrepreneurship. Entrepreneurship Theory and Practice, 40(2), 237-247. doi:10.1111/ etap. 12230 .

Byington, E K, Felps, W, \& Baruch, Y (2019). Mapping the journal of vocational behavior: A 23-year review. Journal of Vocational Behavior, 110, 229-244. doi:10.1016/ j.jvb.2018.07.007.

Carless, S A, \& Arnup, J L (2011). A longitudinal study of the determinants and outcomes of career change. Journal of Vocational Behavior, 78(1), 80-91. doi:10.1016/ j.jvb.2010.09.002.

Chudzikowski, K (2012). Career transitions and career success in the "new" career era. Journal of Vocational Behavior, 81(2), 298-306. doi:10.1016/j.jvb.2011.10.005.

Clarke, M (2008). Understanding and managing employability in changing career contexts. Journal of European Industrial Training, 32(4), 258-284. doi:10.1108/ 03090590810871379.

Cohen, L, \& Mallon, M (1999). The transition from organisational employment to portfolio working: Perceptions of 'boundarylessness. Work, Employment and Society, 13(2), 329-352.

Colakoglu, S N (2011). The impact of career boundarylessness on subjective career success: The role of career competencies, career autonomy, and career insecurity. Journal of Vocational Behavior, 79(1), 47-59. doi:10.1016/j.jvb.2010.09.011.

Croucher, R, Ramakrishnan, S, Rizov, M, \& Benzinger, D (2018). Perceptions of employability among London's low-paid: "Self-determination" or ethnicity? Economic and Industrial Democracy, 39(1), 109-130. doi:10.1177/0143831X15609672.

Dalton, G W, Thompson, P H, \& Price, R L (1977). The four stages of professional careers-A new look at performance by professionals. Organizational Dynamics, 6(1), 19-42. doi:10.1016/0090-2616(77)90033-X.

De Cuyper, N, \& De Witte, H (2011). The management paradox: Self-rated employability and organizational commitment and performance. Personnel Review, 40(1-2), 152-172. doi:10.1108/00483481111106057.

De Cuyper, N, Mäkikangas, A, Kinnunen, U, Mauno, S, \& Witte, H D (2012). Cross-lagged associations between perceived external employability, job insecurity, and exhaustion: Testing gain and loss spirals according to the Conservation of Resources Theory. Journal of Organizational Behavior, 33(6), 770-788. doi:10.1002/ job. 1800.

De Cuyper, N, Mauno, S, Kinnunen, U, \& Makikangas, A (2011). The role of job resources in the relation between perceived employability and turnover intention: A prospective two-sample study. Journal of Vocational Behavior, 78(2), 253-263. doi:10.1016/j.jvb.2010.09.008. 
De Cuyper, N, Raeder, S, Van der Heijden, B I J M, \& Wittekind, A (2012). The association between workers' employability and burnout in a reorganization context: Longitudinal evidence building upon the conservation of resources theory. Journal of Occupational Health Psychology, 17(2), 162-174. doi:10.1037/a0027348.

De Vos, A, Akkermans, J, \& Van der Heijden, B (2019). From occupational choice to career crafting. In Gunz, H, Lazarova, M, \& Mayrhofer, W (Eds.), The Routledge companion to career studies (pp. 128-142). Routledge.

De Vos, A, De Hauw, S, \& Van der Heijden, B I J M (2011). Competency development and career success: The mediating role of employability. Journal of Vocational Behavior, 79(2), 438-447. doi:10.1016/j.jvb.2011.05.010.

De Vos, A, \& Dries, N (2013). Applying a talent management lens to career management: The role of human capital composition and continuity. The International Journal of Human Resource Management, 24(9), 1816-1831. doi:10.1080/09585192.2013.777537.

De Vos, A, Forrier, A, Van der Heijden, B, \& De Cuyper, N (2017). Keep the expert! Occupational expertise, perceived employability and job search a study across age groups. Career Development International, 22(3), 318-332. doi:10.1108/CDI-12-2016-0229.

De Vos, A, \& Soens, N (2008). Protean attitude and career success: The mediating role of self-management. Journal of Vocational Behavior, 73(3), 449-456. doi:10.1016/j.jvb.2008.08.007.

Defillippi, R J, \& Arthur, M B (1994). The boundaryless career: A competency-based perspective. Journal of Organizational Behavior, 15(4), 307-324. doi:10.1002/ job.4030150403.

Direnzo, M S, \& Greenhaus, J H (2011). Job search and voluntary turnover in a boundaryless world: A control theory perspective. Academy of Management Review, 36(3), 567-589. doi:10.5465/AMR.2011.61031812.

Dlouhy, K, \& Biemann, T (2018). Path dependence in occupational careers: Understanding occupational mobility development throughout individuals' careers. Journal of Vocational Behavior, 104, 86-97. doi:10.1016/j.jvb.2017.10.009.

Dragoni, L, Oh, I-S, Vankatwyk, P, \& Tesluk, P E (2011). Developing executive leaders: The relative contribution of cognitive ability, personality, and the accumulation of work experience in predicting strategic thinking competency. Personnel Psychology, 64(4), 829-864. doi:10.1111/j.1744-6570.2011.01229.x.

Eby, L T, Butts, M, \& Lockwood, A (2003). Predictors of success in the era of the boundaryless career. Journal of Organizational Behavior, 24(6), 689-708. doi:10.1002/ job.214.

Equeter, E, Jepsen, D, \& Hellemans, C (2018). Are employees more mobilized after job mobility? Journal of Career Assessment, 26(3), 476-487. doi:10.1177/ 1069072717714542.

Feintuch, A (1955). Improving the employability and attitudes of “difficult-to-place” persons. Psychological Monographs: General and Applied, 69(7), 1-20. doi:10.1037/h0093689.

Feldman, D C, \& Ng, T W H (2007). Careers: Mobility, embeddedness, and success. Journal of Management, 33(3), 350-377. doi:10.1177/0149206307300815.

Forret, M L, Sullivan, S E, \& Mainiero, L A (2010). Gender role differences in reactions to unemployment: Exploring psychological mobility and boundaryless careers. Journal of Organizational Behavior, 31(5, SI), 647-666. doi:10.1002/job.703.

Forrier, A, Cuyper, N D, \& Akkermans, J (2018). The winner takes it all, the loser has to fall: Provoking the agency perspective in employability research. Human Resource Management Journal, 28(4), 511-523. doi:10.1111/1748-8583.12206.

Forrier, A, \& Sels, L (2003). The concept employability: A complex mosaic. International Journal of Human Resources Development and Management, 3, $102-124$.

Forrier, A, Sels, L, \& Stynen, D (2009). Career mobility at the intersection between agent and structure: A conceptual model. Journal of Occupational and Organizational Psychology, 82(4), 739-759. doi:10.1348/096317909X470933.

Forrier, A, Verbruggen, M, \& De Cuyper, N (2015). Integrating different notions of employability in a dynamic chain: The relationship between job transitions, movement capital and perceived employability. Journal of Vocational Behavior, 89, 56-64. doi:10.1016/j.jvb.2015.04.007.

Fouad, N A (2007). Work and vocational psychology: Theory, research, and applications. Annual Review of Psychology, 58(1), 543-564. doi:10.1146/ annurev.psych.58.110405.085713.

Fouad, N A, \& Kozlowski, M B (2019). Turning around to look ahead: Views of vocational psychology in 2001 and 2019. Journal of Career Assessment, 27(3), 375-390. doi:10.1177/1069072719841602.

Fugate, M, \& Kinicki, A J (2008). A dispositional approach to employability: Development of a measure and test of implications for employee reactions to organizational change. Journal of Occupational and Organizational Psychology, 81(3), 503-527. doi:10.1348/096317907X241579.

Fugate, M, Kinicki, A J, \& Ashforth, B E (2004). Employability: A psycho-social construct, its dimensions, and applications. Journal of Vocational Behavior, 65(1), 14-38. doi:10.1016/j.jvb.2003.10.005.

Gati, I, \& Asher, I (2001). Prescreening, in-depth exploration, and choice: From decision theory to career counseling practice. The Career Development Quarterly, 50(2), 140-157. doi:10.1002/j.2161-0045.2001.tb00979.x.

Gesthuizen, M, \& Dagevos, J (2008). Mismatching of persons and jobs in the Netherlands: Consequences for the returns to mobility. Work, Employment and Society, 22(3), 485-506. doi:10.1177/0950017008093482.

Greenhaus, J H, \& Kossek, E E (2014). The contemporary career: A work-home perspective. Annual Review of Organizational Psychology and Organizational Behavior, 1(1), 361-388. doi:10.1146/annurev-orgpsych-031413-091324.

Griffeth, R W, \& Hom, P W (1988). A comparison of different conceptualizations of perceived alternatives in turnover research. Journal of Organizational Behavior, 9(2), 103-111. doi:10.1002/job.4030090202.

Griffeth, R W, \& Hom, P W (1995). The employee turnover process. Research in Personnel and Human Resources Management, 13(3), $245-293$.

Guan, Y, Arthur, M B, Khapova, S N, Hall, R J, \& Lord, R G (2019). Career boundarylessness and career success: A review, integration and guide to future research. Journal of Vocational Behavior, 110, 390-402. doi:10.1016/j.jvb.2018.05.013.

Guan, Y, Yang, W, Zhou, X, Tian, Z, \& Eves, A (2016). Predicting Chinese human resource managers' strategic competence: Roles of identity, career variety, organizational support and career adaptability. Journal of Vocational Behavior, 92, 116-124. doi:10.1016/j.jvb.2015.11.012.

Gunz, H, Peiperl, M, \& Tzabbar, D (2007). Boundaries in the study of career. In Gunz, H, \& Peiperl, M (Eds.), Handbook of career studies (pp. 471-494). Sage.

Haibo, Y, Xiaoyu, G, Xiaoming, Z, \& Zhijin, H (2018). Career adaptability with or without career identity: How career adaptability leads to organizational success and individual career success? Journal of Career Assessment, 26(4), 717-731. doi:10.1177/1069072717727454.

Håkansson, K, \& Isidorsson, T (2015). Temporary agency workers-Precarious workers? Perceived job security and employability for temporary agency workers and client organization employees at a Swedish manufacturing plant. Nordic Journal of Working Life Studies, 5(4), 3-22. doi:10.19154/njwls.v5i4.4841.

Hall, D T (1976). Careers in organizations. Goodyear Pub. Co..

Hall, D T, \& Mirvis, P H (1996). The new protean career: Psychological success and the path with a heart. In Hall, D T (Ed.), et al., The career is dead-Long live the career: A relational approach to careers (pp. 15-45). Jossey-Bass.

Hall, D T (2004). The protean career: A quarter-century journey. Journal of Vocational Behavior, 65(1), 1-13. doi:10.1016/j.jvb.2003.10.006.

Hall, D T, \& Las Heras, M (2010). Reintegrating job design and career theory: Creating not just good jobs but "smart" jobs. Journal of Organizational Behavior, 31(2/ 3), 448-462. (JSTOR).

Herriot, P, \& Pemberton, C (1995). Competitive advantage through diversity: Organizational learning from difference. Sage Publications, Inc..

Heslin, P, Keating, L A, \& Ashford, S J (2019). How being in learning mode may enable a sustainable career across the lifespan. Journal of Vocational Behavior, 103324. doi:10.1016/j.jvb.2019.103324.

Hillage, J, \& Pollard, E (1998). Employability: Developing a framework for policy analysis (Vol. 107). DfEE.

Hirschi, A (2012). The career resources model: An integrative framework for career counsellors. British Journal of Guidance and Counselling, 40, 369-383. doi:10.7892/ boris. 62512 .

Hobfoll, S E (1989). Conservation of resources: A new attempt at conceptualizing stress. American Psychologist, 513-524.

Holland, J L (1958). A personality inventory employing occupational titles. Journal of Applied Psychology, 42(5), 336-342. doi:10.1037/h0047330.

Hom, P W, Lee, T W, Shaw, J D, \& Hausknecht, J P (2017). One hundred years of employee turnover theory and research. Journal of Applied Psychology, 102(3), 530-545. doi:10.1037/apl0000103.

Hom, P W, Mitchell, T R, Lee, T W, \& Griffeth, R W (2012). Reviewing employee turnover: Focusing on proximal withdrawal states and an expanded criterion. Psychological Bulletin, 138(5), 831.

Kalleberg, A L, \& Mastekaasa, A (2001). Satisfied movers, committed stayers: The impact of job mobility on work attitudes in Norway. Work and Occupations, 28(2), 183-209. doi:10.1177/0730888401028002004.

Kirves, K, Kinnunen, U, \& De Cuyper, N (2014). Contract type, perceived mobility and optimism as antecedents of perceived employability. Economic and Industrial Democracy, 35(3), 435-453. doi:10.1177/0143831X13486702. 
Koen, J, Klehe, U-C, \& Van Vianen, A E M (2013). Employability among the long-term unemployed: A futile quest or worth the effort? Journal of Vocational Behavior, 82(1), 37-48. doi:10.1016/j.jvb.2012.11.001.

Kornblum, A, Unger, D, \& Grote, G (2018). When do employees cross boundaries? Individual and contextual determinants of career mobility. European Journal of Work and Organizational Psychology, 27(5), 657-668. doi:10.1080/1359432X.2018.1488686.

Kovalenko, M, \& Mortelmans, D (2014). Does career type matter? Outcomes in traditional and transitional career patterns. Journal of Vocational Behavior, 85(2), 238-249. doi:10.1016/j.jvb.2014.07.003.

Kozlowski, S W J, Chao, G T, Grand, J A, Braun, M T, \& Kuljanin, G (2013). Advancing multilevel research design: Capturing the dynamics of emergence. Organizational Research Methods, 16(4), 581-615. doi:10.1177/1094428113493119.

Kraimer, M L, Seibert, S E, Wayne, S J, Liden, R C, \& Bravo, J (2011). Antecedents and outcomes of organizational support for development: The critical role of career opportunities. Journal of Applied Psychology, 96(3), 485-500. doi:10.1037/a0021452.

Krumboltz, H B, \& Shapiro, J (1979). Counseling women in behavioral self-direction. The Personnel and Guidance Journal, 57(8), 415-418. doi:10.1002/ j.2164-4918.1979.tb05425.x.

Krumboltz, J (1979). A social learning theory of career decision making. In Mitchell, A M, Jones, G B, \& Krumboltz, J D (Eds.), Social learning and career decision making (pp. 19-49). Carroll Press.

Latack, J C (1984). Career transitions within organizations: An exploratory study of work, nonwork, and coping strategies. Organizational Behavior and Human Performance, 34(3), 296-322. doi:10.1016/0030-5073(84)90041-2.

Lent, R W, \& Brown, S D (2006). Integrating person and situation perspectives on work satisfaction: A social-cognitive view. Journal of Vocational Behavior, 69(2), 236-247. doi:10.1016/j.jvb.2006.02.006.

Lent, R W, Brown, S D, \& Hackett, G (1994). Toward a unifying social cognitive theory of career and academic interest, choice, and performance. Journal of Vocational Behavior, 45(1), 79-122. doi:10.1006/jvbe.1994.1027.

LoPresti, A, Pluviano, S, \& Briscoe, J P (2018). Are freelancers a breed apart? The role of protean and boundaryless career attitudes in employability and career success. Human Resource Management Journal, 28(3), 427-442. doi:10.1111/1748-8583.12188.

Lu, C, Sun, J, \& Du, D (2016). The relationships between employability, emotional exhaustion, and turnover intention: The moderation of perceived career opportunity. Journal of Career Development, 43(1, SI), 37-51. doi:10.1177/0894845315576372.

Maertz, C P, \& Kmitta, K R (2012). Integrating turnover reasons and shocks with turnover decision processes. Journal of Vocational Behavior, 81(1), 26-38. doi:10.1016/ j.jvb.2012.04.002.

Magnum, G L (1976). Employability, employment, and income. Salt Lake City, UT: Olympus.

Mai, K M, Ellis, A P J, Christian, J S, \& Porter, C O L H (2016). Examining the effects of turnover intentions on organizational citizenship behaviors and deviance behaviors: A psychological contract approach. Journal of Applied Psychology, 101(8), 1067-1081. doi:10.1037/apl0000115.

March, J G, \& Simon, H A (1958). Organizations. Wiley.

McArdle, S, Waters, L, Briscoe, J P, \& Hall, D T(T) (2007). Employability during unemployment: Adaptability, career identity and human and social capital. Journal of Vocational Behavior, 71(2), 247-264. doi:10.1016/j.jvb.2007.06.003.

McPherson, R (2018). Low-qualified labors' job mobility, boundary crossing, and career success: A cross-industry HRM perspective. Journal of Organizational Psychology, 18(1), 116-129.

Michaels, C E, \& Spector, P E (1982). Causes of employee turnover: A test of the Mobley, Griffeth, Hand, and Meglino model. Journal of Applied Psychology, 67(1), 53-59. doi:10.1037/0021-9010.67.1.53.

Mirvis, P H, \& Hall, D T (1994). Psychological success and the boundaryless career. Journal of Organizational Behavior, 15(4), 365-380. doi:10.1002/job.4030150406.

Mitchell, T R, Holtom, B C, Lee, T W, Sablynski, C J, \& Erez, M (2001). Why people stay: Using job embeddedness to predict voluntary turnover. Academy of Management Journal, 44(6), 1102-1121.

Mobley, W H (1977). Intermediate linkages in the relationship between job satisfaction and employee turnover. Journal of Applied Psychology, 62(2), 237-240. doi:10.1037/0021-9010.62.2.237.

Mobley, W H, Griffeth, R W, Hand, H H, \& Meglino, B M (1979). Review and conceptual analysis of the employee turnover process. Psychological Bulletin, 86(3), 493-522. doi:10.1037/0033-2909.86.3.493.

Moyle, P, \& Parkes, K (1999). The effects of transition stress: A relocation study. Journal of Organizational Behavior, 20(5), 625-646. doi:10.1002/ (SICI)1099-1379(199909)20:5<625::AID-JOB898>3.0.CO;2-7.

Nagy, N, Froidevaux, A, \& Hirschi, A (2018). Lifespan perspectives on careers and career development. In Baltes, B, Rudolph, C, \& Zacher, H (Eds.), Work across the lifespan (pp. 1-43). Elsevier.

Neiner, A G, \& Owens, W A (1985). Using biodata to predict job choice among college graduates. Journal of Applied Psychology, 70(1), 127-136. doi:10.1037/ 0021-9010.70.1.127.

Nelissen, J, Forrier, A, \& Verbruggen, M (2017). Employee development and voluntary turnover: Testing the employability paradox. Human Resource Management Journal, 27(1), 152-168. doi:10.1111/1748-8583.12136.

Ng, T W H, Sorensen, K L, Eby, L T, \& Feldman, D C (2007). Determinants of job mobility: A theoretical integration and extension. Journal of Occupational and Organizational Psychology, 80(3), 363-386. doi:10.1348/096317906X130582.

Nicholson, N, \& West, M (1989). Transitions, work histories, and careers. In Arthur, M B, Hall, D T, \& Lawrence, B S (Eds.), Handbook of career theory (pp. 181-201). Cambridge University Press.

Nicholson, N (1984). A theory of work role transitions. Administrative Science Quarterly, 29(2), 172-191. JSTOR https://doi.org/10.2307/2393172.

O'Mahony, S, \& Bechky, B A (2006). Stretchwork: Managing the career progression paradox in external labor markets. Academy of Management Journal, 49(5), 918-941. doi:10.5465/amj.2006.22798174.

Parsons, F (1909). Choosing a vocation. Hougthon-Mifflin.

Patton, W, \& McMahon, M (2014). Career development and systems theory: Connecting theory and practice. Springer.

Peeters, E, Nelissen, J, De Cuyper, N, Forrier, A, Verbruggen, M, \& De Witte, H (2019). Employability capital: A conceptual framework tested through expert analysis. Journal of Career Development, 46(2), 79-93. doi:10.1177/0894845317731865.

Pinder, C C, \& Schroeder, K G (1987). Time to proficiency following job transfers. Academy of Management Journal, 30(2), 336-353. doi:10.5465/256278.

Pryor, R, \& Bright, J (2011). The chaos theory of careers: A new perspective on working in the twenty-first century. Routledge.

Raemdonck, I, Tillema, H, de Grip, A, Valcke, M, \& Segers, M (2012). Does self-directedness in learning and careers predict the employability of low-qualified employees? Vocations and Learning, 5(2), 137-151. doi:10.1007/s12186-011-9072-7.

Rodrigues, R A, \& Guest, D (2010). Have careers become boundaryless? Human Relations, 63(8), 1157-1175. doi:10.1177/0018726709354344.

Rothwell, A, \& Arnold, J (2007). Self-perceived employability: Development and validation of a scale. Personnel Review, 36(1), 23-41. doi:10.1108/ 00483480710716704 .

Sarason, S B (1977). Work, aging, and social change: Professionals and the one life-one career imperative. Free Press.

Savickas, M L (1994). Measuring career development: Current status and future directions. The Career Development Quarterly, 43(1), 54-62. doi:10.1002/ j.2161-0045.1994.tb00846.x.

Savickas, M L (2011). New questions for vocational psychology: Premises, paradigms, and practices. Journal of Career Assessment, 19(3), 251-258. doi:10.1177/ 1069072710395532.

Savickas, M L, \& Porfeli, E J (2012). Career Adapt-Abilities Scale: Construction, reliability, and measurement equivalence across 13 countries. Journal of Vocational Behavior, 80(3), 661-673. doi:10.1016/j.jvb.2012.01.011.

Schultz, M, \& Hernes, T (2012). A temporal perspective on organizational identity. Organization Science, 24(1), 1-21. doi:10.1287/orsc.1110.0731.

Short, J (2009). The art of writing a review article. Journal of Management, 35(6), 1312-1317. doi:10.1177/0149206309337489.

Stahl, G K, Miller, E L, \& Tung, R L (2002). Toward the boundaryless career: A closer look at the expatriate career concept and the perceived implications of an international assignment. Journal of World Business, 37(3), 216-227. doi:10.1016/S1090-9516(02)00080-9.

Steers, R M, \& Mowday, R T (1981). Employee turnover and post-decision justification. In Cummings, L L, \& Staw, B M (Eds.), Research in organizational behavior (Vol. 3, pp. 235-282). JAI Press. 
Stengard, J, Bernhard-Oettel, C, Berntson, E, \& Leineweber, C (2017). Stuck in the job: Does helplessness precede being locked-in at the workplace or vice versa? An analysis of cross-lagged effects. Journal of Vocational Behavior, 102, 15-27. doi:10.1016/j.jvb.2017.06.001.

Stengard, J, Bernhard-Oettel, C, Berntson, E, Leineweber, C, \& Aronsson, G (2016). Stuck in a job: Being "locked-in" or at risk of becoming locked-in at the workplace and well-being over time. Work and Stress, 30(2), 152-172. doi:10.1080/02678373.2016.1163804.

Stumpf, S A (2014). A longitudinal study of career success, embeddedness, and mobility of early career professionals. Journal of Vocational Behavior, 85(2), 180-190. doi:10.1016/j.jvb.2014.06.002.

Sullivan, S E, \& Arthur, M B (2006). The evolution of the boundaryless career concept: Examining physical and psychological mobility. Journal of Vocational Behavior, 69(1), 19-29. doi:10.1016/j.jvb.2005.09.001.

Sullivan, S E, \& Baruch, Y (2009). Advances in career theory and research: A critical review and agenda for future exploration. Journal of Management, 35(6), 1542-1571. doi:10.1177/0149206309350082.

Super, D E (1957). The psychology of careers; An introduction to vocational development. Harper \& Bros.

Swanson, J L, \& Gore, P A (2000). Advances in vocational psychology theory and research. Handbook of counseling psychology (3rd ed., pp. 233-269). John Wiley \& Sons Inc.

Swider, B W, Boswell, W R, \& Zimmerman, R D (2011). Examining the job search-turnover relationship: The role of embeddedness, job satisfaction, and available alternatives. Journal of Applied Psychology, 96(2), 432-441. doi:10.1037/a0021676.

Takeuchi, R, Chen, G, \& Lepak, D P (2009). Through the looking glass of a social system: Cross-level effects of high-performance work systems on employees' attitudes. Personnel Psychology, 62(1), 1-29.

Thijssen, J G L, Van der Heijden, B I J M, \& Rocco, T S (2008). Toward the employability_Link model: Current employment transition to future employment perspectives. Human Resource Development Review, 7(2), 165-183. doi:10.1177/1534484308314955.

Tran, H, Baruch, Y, \& Bui, H T (2019). On the way to self-employment: The dynamics of career mobility. International Journal of Human Resource Management, 1-25.

Trevor, C O (2001). Interactions among actual ease-of-movement determinants and job satisfaction in the prediction of voluntary turnover. Academy of Management Journal, 44(4), 621-638. doi:10.5465/3069407.

Van der Heijde, C M, \& Van der Heijden, B I J M (2006). A competence-based and multidimensional operationalization and measurement of employability. Human Resource Management, 45(3), 449-476. doi:10.1002/hrm.20119.

Van der Heijden, B, Mahoney, C B, \& Xu, Y (2019). Impact of job demands and resources on nurses' burnout and occupational turnover intention towards an age-moderated mediation model for the nursing profession. International Journal of Environmental Research and Public Health, 16(11). doi:10.3390/ ijerph16112011.

Van der Heijden, B I J M, de Lange, A H, Demerouti, E, \& Van der Heijde, C M (2009). Age effects on the employability-career success relationship. Journal of Vocational Behavior, 74(2), 156-164. doi:10.1016/j.jvb.2008.12.009.

Van der Heijden, B I J M, \& De Vos, A (2015). Sustainable careers: Introductory chapter. Handbook of research on sustainable careers. https://www.elgaronline.com/ view/edcoll/9781782547020/9781782547020.00006.xml.

Van Esbroeck, R V, Tibos, K, \& Zaman, M (2005). A dynamic model of career choice development. International Journal for Educational and Vocational Guidance, 5(1), 5-18. doi:10.1007/s10775-005-2122-7.

van Harten, J, Knies, E, \& Leisink, P (2016). Employer's investments in hospital workers' employability and employment opportunities. Personnel Review, 45(1), 84-102. doi:10.1108/PR-05-2014-0115.

Vanhercke, D, De Cuyper, N, Peeters, E, \& De Witte, H (2014). Defining perceived employability: A psychological approach. Personnel Review, 43(4), 592-605. doi:10.1108/PR-07-2012-0110.

Vantilborgh, T, Hofmans, J, \& Judge, T A (2018). The time has come to study dynamics at work. Journal of Organizational Behavior, 39(9), 1045-1049. doi:10.1002/ job.2327.

Veld, M, Semeijn, J, \& van Vuuren, T (2015). Enhancing perceived employability an interactionist perspective on responsibilities of organizations and employees. Personnel Review, 44(6), 866-882. doi:10.1108/PR-05-2014-0100.

Verbruggen, M (2012). Psychological mobility and career success in the "new" career climate. Journal of Vocational Behavior, 81(2), 289-297. doi:10.1016/ j.jvb.2011.10.010.

Verbruggen, M, De Cooman, R, \& Vansteenkiste, S (2015). When and why are internal job transitions successful? Transition challenges, hindrances, and resources influencing motivation and retention through basic needs satisfaction. Group \& Organization Management, 40(6), 744-775. doi:10.1177/1059601115595935.

Verbruggen, M, \& De Vos, A (2020). When people don't realize their career desires: Toward a theory of career inaction. Academy of Management Review. doi:10.5465/ amr.2017.0196.

Verbruggen, M, \& Sels, L (2010). Social-cognitive factors affecting clients' career and life satisfaction after counseling. Journal of Career Assessment, 18(1), 3-15. doi:10.1177/1069072709340516.

Verbruggen, M, \& van Emmerik, H (2018). When staying is dissatisfying: Examining when and why turnover cognitions affect Stayers' career satisfaction. Journal of Management. doi:10.1177/0149206318801998. 0149206318801998.

Wang, M, \& Wanberg, C R (2017). 100 years of applied psychology research on individual careers: From career management to retirement. Journal of Applied Psychology, 102(3), 546-563. doi:10.1037/apl0000143.

Wang, M, Zhou, L, \& Zhang, Z (2016). Dynamic modeling. Annual Review of Organizational Psychology and Organizational Behavior, 3(1), 241-266. doi:10.1146/ annurev-orgpsych-041015-062553.

Watts, A G (1996). Toward a policy for lifelong career development: A transatlantic perspective. The Career Development Quarterly, 45(1), 41-53. doi:10.1002/ j.2161-0045.1996.tb00460.x.

Watts, A G (2005). Career guidance policy: An international review. The Career Development Quarterly, 54(1), 66-76. doi:10.1002/j.2161-0045.2005.tb00142.x.

West, M A, Nicholson, N, \& Rees, A (1987). Transitions into newly created jobs. Journal of Occupational Psychology, 60(2), 97-113. doi:10.1111/ j.2044-8325.1987.tb00244.x.

Wheeler, A R, Coleman Gallagher, V, Brouer, R L, \& Sablynski, C J (2007). When person-organization (mis)fit and (dis)satisfaction lead to turnover: The moderating role of perceived job mobility. Journal of Managerial Psychology, 22(2), 203-219. doi:10.1108/02683940710726447.

Wittekind, A, Raeder, S, \& Grote, G (2010). A longitudinal study of determinants of perceived employability. Journal of Organizational Behavior, 31(4), 566-586. doi:10.1002/job.646. 